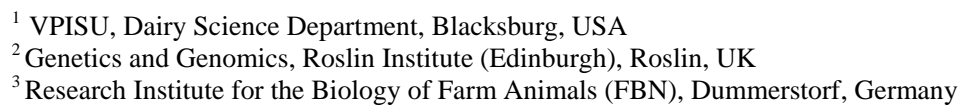

GERTRAUDE FREYER ${ }^{3}$, JULES HERNÁNDEZ-SÁNCHEZ ${ }^{2}$ and BENNET G. CASSELL ${ }^{1}$

\title{
A note on inbreeding in dairy cattle breeding
}

\author{
Dedicated to Prof. Dr. sc. Lothar Panicke on the occasion of his $65^{\text {th }}$ birthday
}

\begin{abstract}
Starting from the study at the beginning of the East German "Heterosisfeldversuch", where PANICKE et al. (1975) considered the possibilities of a targeted use of inbreeding and heterotic effects, we show and discuss results of inbreeding studies in the USA dairy cattle breeding. Several research groups worldwide presented effective tools for managing inbreeding in dairy cattle. Their efforts underline the need of inbreeding studies. Contemplating inbreeding is necessary for any breeding decision to avoid inbreeding depression and for improved genetic analyses, e.g. in QTL- estimation. A novel methodology (HERNANDEZ-SANCHEZ et al., 2004a and b) is suggested for estimating inbreeding at the three levels of population, individual and locus.
\end{abstract}

Key Words: inbreeding, dairy cattle, heterosis, rate of inbreeding

\section{Zusammenfassung}

Titel des Beitrages: Eine Betrachtung zur Inzucht in der Milchrindzüchtung

Ausgehend von der Studie zum „Heterosisfeldversuch“ in Ostdeutschland, in der PANICKE u.a. (1975) die Möglichkeiten einer planmäßigen Nutzung von Inzucht und Heterosis in der Milchrindzüchtung behandelten, stellen wir Ergebnisse zur Inzuchtschätzung aus den USA vor. Die Tatsache, dass Forschergruppen weltweit effektive Methoden zur Vorhersage, Schätzung und Handhabung von Inzucht erarbeiten, unterstreicht die Bedeutung, die diesem Phänomen international beigemessen wird. Die Berücksichtigung von Inzucht ist bedeutsam für jede Zuchtentscheidung zur Vermeidung von Inzuchtdepression sowie für verbesserte genetische Analysen, z.B. in der QTL-Schätzung. Eine neue Methode (HERNÁNDEZ-SÁNCHEZ u.a., 2004a und b), die eine Inzuchtschätzung innerhalb Population, Individuum und Locus ermöglicht, erscheint vielversprechend.

Schlüsselwörter: Inzucht, Milchrind, Heterosis, Inzuchtrate

\section{Introduction}

PANICKE et al. (1975) monitored inbreeding within a basic study in the former East German dairy cattle breeding research, so called 'Heterosisfeldversuch'. This experiment was set up in order to quantify heterotic effects expected by the threebreed-cross 'Black Pied Dairy Cattle' during the 1970s and 1980s. Holstein Friesian, Danish Jersey and the original East German Black and White were the three breeds involved in this large experiment. The results of the experiment were published, mainly with respect to the additive breed effects and heterotic effects on milk production, growth and fertility (e.g. PANICKE and FREYER, 1992). Inbreeding depression and heterozygosity are closely connected to the mating systems occurring as a result either from inbreeding or from crossing. Increasing genetic variability and vigour after crossing and decreasing genetic variability and vitality after inbreeding are different expressions of basically the same phenomenon. The physiological power of 
an organism, established by its growth and general robustness is positively correlated to the degree of variety between the gametes forming the individual organism (SHULL, 1914, cit. by PANICKE et al., 1975). The opposite of it is the inbreeding depression with homozygosity being the main cause. Genes for recessive diseases are not the only source of inbreeding depression. Mating of relatives increases genetic similarity, because parental genes being identical by descent and having the same effects concur after fertilisation. Inbreeding means mating of related animals, which also means that the amount of relation is closer in these animals than among random individuals of the population. The co-variances between parents and inbred progeny are influenced by the corresponding non-additive effects in the presence of dominance (BRADE, 1991).

Inbreeding leads to a reduction of unequal allelic pairs (see Figure). Inbreeding depression in general is expected to be followed by decreasing vitality, declining of adaptability and fertility traits and growth as confirmed by ZELLER and PIRCHNER (1993) for example. Increasing probability of losing favourable alleles due to a decline in heterozygosity by mating relatives are the main reasons. Thus, inbreeding can reduce the commercial exploitation in dairy herds. In recent years, novel methods for controlling inbreeding in selection programmes have been investigated. Some of them will be mentioned within our note on inbreeding.

The aim of the paper is to monitor some new results of investigating inbreeding especially from USA dairy cattle breeding, perhaps inducing thoughts on the importance of similar extensive investigations in Germany. Using a novel method that can be used for four and more loci and works independently from pedigree information (HERNÁNDEZ-SÁNCHEZ et al., 2004a) would be an interesting aspect herein. Further, this methodology enables computing inbreeding measures at the three levels and provides a step forward in adapting to advanced QTL analyses as well (HERNÁNDEZ-SÁNCHEZ et al., 2004b).

\section{New aspects on the traditional measure of inbreeding}

Population parameters such as inbreeding coefficients are the basis of quantitative genetic theory. There are three levels in which inbreeding can be estimated: population level, individual level, and locus level. The less specific inbreeding estimator is the population average, which applies to all individuals and loci. The mean population inbreeding can be readily calculated, given some evolutionary assumptions, as

$$
F_{t}=1-(1-\Delta F)^{t}
$$

where $F_{t}$ is the inbreeding at a time (generation) $t, \Delta F=1 / 2 N$ is the rate of increase of inbreeding per generation, and $N$ is the effective population size. This formula assumes a fixed population size, discrete generations, and neither migration nor mutation. It can accommodate selection through calculation of appropriate $\mathrm{N}$ values. In addition to being the mean population inbreeding, $\mathrm{F}_{\mathrm{t}}$ is also the expected inbreeding coefficient at each single locus, given the aforementioned conditions. WEIR and COCKERHAM (1969) extended the theory from one locus to two loci population inbreeding coefficient, i.e. their digenic descent measures. This theory included a new parameter, i.e. distance between loci in recombination units. It is an exact theory that included one locus population inbreeding calculations as a special case, i.e. when recombination rate 
is zero. HERNÁNDEZ-SÁNCHEZ et al. (2004a) extended the two loci theory to predict three and four loci population inbreeding coefficients using a regression model. Their method is an accurate approximation, and it could theoretically be extended to predict population inbreeding at n-loci simultaneously $(n>4)$. The advantage of this method for practical use is its independency on pedigree information. It has been assumed that a population is undergoing genetic drift over $T$ discrete generations, with constant size, random mating. The inbreeding coefficient $F_{A B C D}$ is more sensitive to $N$ than to distance $d$ between loci. This result was confirmed by a different study presenting an algorithm to calculate epistatic kinship and epistatic inbreeding (FLURY and SIMIANER, 2004). In practice, a researcher could reduce the standard error of $d$ by increasing the sample size.

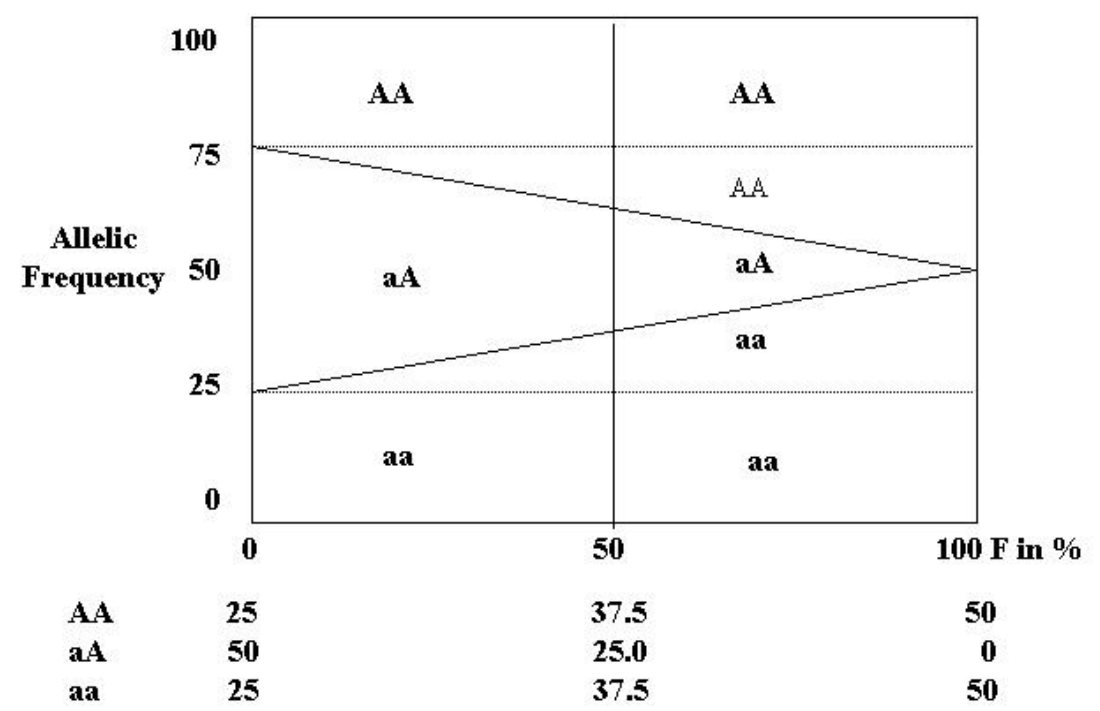

Figure: Inbreeding rate $(F)$ in dependence on allelic frequency at one locus (LE ROY 1966, cit. by PANICKE et al., 1975). (Inzuchtrate $(F)$ in Abhängigkeit von der Allelfrequenz an einem Locus).

The next level of specificity is inbreeding at individual level. This inbreeding coefficient depends on a specific pedigree and therefore it can differ across individuals, although it is the same across all loci within an individual. The most adapted measure for describing this sort of inbreeding is as described by WRIGHT (1922)

$$
F_{k}=\sum(1 / 2)^{n 1+n 2+1}\left(1+F_{A}\right),
$$

with $F_{k}$ - inbreeding coefficient of individual $k, n 1$ (n2)- number of paternal (maternal) generations between the parents of $k$ and common ancestor, $F_{A^{-}}$inbreeding coefficient of inbred ancestor and $\sum$ notes the summation in case of multiple inbreeding due to the same or several common ancestors. For large data sets, it is necessary to rely on much faster methods such as the relationship matrix. A way of calculating the expected inbreeding per individual given a pedigree is to subtract 1 to the diagonal of the average relationship matrix (LYNCH and WALSH, 1998).

The sharpest level of specificity is the inbreeding coefficient at locus level. This estimator requires marker information, and thus, it differs between loci, within and 
between individuals. There are basically two ways of calculating this type of inbreeding coefficient, deterministic methods which are fast but cannot make use of all marker information, e.g. missing genotypes, (e.g. PONG-WONG et al., 2001; WANG et al., 1995), and MCMC methods which are more computationally demanding, but that can make use of all available information (e.g. THOMPSON and HEATH, 1999). More information can still be used to predict locus specific inbreeding. For example, if the history of a population was approximately known, then it could be used to predict coancestry among pedigree founders, otherwise assumed unrelated, and subsequently use the above methods to predict inbreeding among all individuals in the pedigree (MEUWISSEN and GODDARD, 2002; HERNÁNDEZ-SÁNCHEZ et al., 2004b). These methods combine pedigree with marker information, and also historical information, to predict coancestry, i.e. genetic relationship, among all individuals. The inbreeding coefficient is part of one's coancestry with him/herself. The specific locus inbreeding (calculated as in HERNÁNDEZ-SÁNCHEZ et al., 2004b) can be used to estimate inbreeding profiles along chromosomes for each individual, which further could be used to design more specific breeding programs, for example, avoiding inbreeding in chromosomal regions containing recessive deleterious genes, or selecting among pure lines chromosomal regions containing genes affecting hybrid vigour.

\section{Recent studies on inbreeding in dairy cattle in USA and elsewhere}

Inbreeding depression per $1 \%$ increase of inbreeding was predicted to be up to $-30 \mathrm{~kg}$ milk, $-1.0 \mathrm{~kg}$ fat and $-1.5 \mathrm{~kg}$ body weight (PANICKE et al., 1975). This prediction was confirmed by an extensive study based on individual level within the population, carried out by SMITH et al. (1998) and CASSELL et al. (2003a and b) in the USA. The estimated inbreeding depression on milk yield in first lactation amounted to -27 $\mathrm{kg}$, fat yield and protein yield -0.9 and $-0.8 \mathrm{~kg}$. For the whole life time the depression was $-177 \mathrm{~kg}$ milk, $-6 \mathrm{~kg}$ fat and $-5.5 \mathrm{~kg}$ protein, per $1 \%$ increase of inbreeding. Further, the inbreeding depression in age of first calving was +0.55 days, -6 days of productive life and -4.8 milking days. There was no large effect on conformation traits.

Current trends toward increased relationship between daughters of frequently used sires indicate that inbreeding will become increasingly difficult to avoid in the future. Increased relationships are a natural consequence of selection to improve the dairy cow (CASSELL, 2001). Long-term effects are an inevitable increase in dairy herds that rely on traditional sources of germplasm. Additional costs of inbreeding arise from early embryonic death, losses in calves and heifers, lower growth rates and infertility. The use of bulls unrelated to females produced by standard genetic improvement programs would decrease genetic improvement because of lower additive genetic improvement by excluding potential mates. It is recommended, that the herd manager should manage inbreeding and selection jointly, rather than to avoid inbreeding altogether. WEIGEL and LIN (2000) showed options to manage inbreeding while avoiding it above specified maximums including mating programs. A pedigree constructed to reduce relationships between sire and dam would produce a pedigree offering fewer options for similar mate selection in the next generation. Breeding strategies to control inbreeding losses in producing females might prove sustainable if progeny tested males were more inbred than they are at present. Inbreeding can also result from multiple common ancestors three to five generations back for potential 
mating pairs. Further results show both average estimates of inbreeding and variation in those estimates are suppressed by incomplete pedigree information.

CASSELL, ADAMEC and PEARSON (2003a) demonstrated an algorithm for calculating the inbreeding depression in dependence on the amount of available pedigree information using the classical pedigree approach as a basis to calculate inbreeding. The approach was used in a study on effects of inbreeding on days to first service and summit milk yield using repeated records on large files of Holstein and Jersey cows. The animal model used to estimate inbreeding effects was

$$
Y_{i j k l}=H Y S_{i}+P_{j}+\beta\left(F_{k}\right)+A_{k}+P E_{k}+E_{i j k l},
$$

with (repeated) observations of interval to first breeding or summit milk yield $Y_{i j k l}$ of cow $k$ in her jth parity calving in the ith herd-year-season $H Y S_{i}, P_{j}$ fixed effect of the jth parity ( 1 to 4 ), $\beta$ is the regression of the considered trait on inbreeding, $A_{k}$ is the additive genetic effect of cow $k$, and $P E_{k}$ and $E_{i j k l}$ are the permanent environmental and residual effects on cow $k$, respectively. Pedigree completeness was based on male and female ancestors in six generation pedigrees with 1960 base year for pedigree information. This study showed that both the mean inbreeding coefficient $F x$ of the population in percent (\%) and the inbreeding depression estimate were affected by the amount of pedigree information. Inbreeding and its standard deviation increased with more information from $0.04 \pm 0.84$ to $2.06 \pm 2.22$ for high yielding Holsteins with $<31 \%$ and $>71 \%$ complete five-generation pedigrees. A small inconsistently significant inbreeding effect on days to first service was found. Partial pedigrees reduce the average inbreeding estimate and the variance of such estimates in groups of cows. The same study tested an average relationship method to replace missing pedigree information. The approach evaluated was not an effective replacement for the missing information for purposes of estimating the effects of inbreeding on animal performance.

Table

Effects of inbreeding in Jersey and Holstein cows or in the fetus on calving rate in first lactation (CASSELL, ADAMEC, PEARSON, 2003b) (Effekte der Inzucht von Kühen/Feten auf die Kalberate, innerhalb der Rassen Jersey und Holstein)

\begin{tabular}{ccccc}
\hline Breed & $\begin{array}{c}\text { Inbreeding of dam } \\
F_{X}\end{array}$ & $\begin{array}{c}\text { Inbreeding } \\
\text { depression } / 1 \% F_{X}\end{array}$ & $\begin{array}{c}\text { Using inbreeding of } \\
\text { fetus } F x\end{array}$ & $\begin{array}{c}\text { Inbreeding depression } / 1 \% \\
F_{X}\end{array}$ \\
\hline Holstein & $3.68 \pm 2.35$ & $-0.004 \pm 0.001$ & $4.46 \pm 2.19$ & $-0.004 \pm 0.001$ \\
& & Mean for calving rate \pm standard deviation: $0.40 \pm 0.49$ & $-0.004 \pm 0.002$ \\
Jersey & $4.62 \pm 2.79$ & $-0.006 \pm 0.002$ & $5.96 \pm 2.89$ & $-0.45 \pm 0.50$ \\
& & Mean for calving rate \pm standard deviation: 0.45 & \\
\hline
\end{tabular}

Effects of inbreeding in the dam and in the fetus on calving rates in different parities of Holstein and Jersey cows using large files of field data were examined as well (CASSELL, ADAMEC and PEARSON, 2003 b). Only Holsteins and Jerseys with substantially complete six-generation pedigrees were included. Small, undesirable, but not consistently significant inbreeding effects on 70d non-return rate and calving rate were estimated (Table). These results showed substantial increases in average inbreeding from dams to the calves they carried. Documentation of increasing inbreeding, even in very large dairy cattle populations, exists (AIPL trends for inbreeding in Holstein cows, 2004). If not altered by future efforts to control them, such trends will lead to numerous harmful effects such as an increase in the difficulty 
of maintaining acceptable reproductive performance in dairy cattle in the future. Pedigree data for multiple generations will assume a higher economic value as inbreeding increases in future increasingly related dairy population.

New investigations by SORENSEN et al. (2004) yielded $3.4 \%$ average inbreeding for Danish Holstein and 1.3 \% for Danish Red, for calves born in 2003. The authors concluded that Danish Holstein is very close to the minimum effective population size and tools are needed to monitor the selection process in order to control inbreeding. In Danish Red, a synthetic population, considerably more genetic diversity holds and if importations will continue, less inbreeding problems should be expected. A similar conclusion was drawn by BIEDERMANN et al. (2003) after investigating the small Hinterwälder cattle breed. PIRCHNER (2002) estimated the increase in inbreeding in Bavarian Fleckvieh and Tyrolean Grey within different time courses between 1960 and 2000 within a study on estimating the effective population size from changes in allelic frequencies of blood types and milk proteins.

Researchers worldwide presented effective tools dealing with and managing inbreeding in dairy cattle. Here, we have to restrict on mentioning some of them which seem promising to meet the needs at the present time. A strategy for achieving the lowest possible rate of inbreeding $(\Delta F)$ with random mating was presented by SANCHEZ et al. (2003). Reductions in $\Delta F$ obtained from random mating arise from preferential mating of relatives and not from their avoidance as already mentioned. Current breeding software, such as "Total Genetic Resource Managements" from the University of New England in Armidale/Australia

(www-personal.une.edu.au/ bkinghor/matesel.htm) or SelAction from Wageningen University in The Netherlands (www.zod.wau.nl/abg/selaction), find mating strategies providing a given genetic gain at a fixed inbreeding rate, by optimising long-term genetic contributions of ancestors (e.g. BIJMA and WOOLIAMS, 1999). The given web-links will provide interested readers with additional details.

\section{Outlook}

Investigations in using effects of crossbreeding in dairy cattle breeding have become popular again in Germany as well (e.g. SWALVE, 2002). In contrary to such investigations focused on crossbreeding effects on performances, the present SEGFAM experiment based on an experimental crossing between Charolais and German Holstein is aimed at investigating in the genetic and physiologic basis of phenotypic traits in segregating family structures (KÜHN et al., 2002). The opposite of this inherent phenomenon is inbreeding. PIRCHNER (2004) suggested the use of inbred sires in selection to exploit epistatic effects in addition to average gene effects. The broad range of international literature suggests potential benefits to additional studies on the effects of inbreeding on populations, individuals, and specific gene loci. The most promising way of predicting co-ancestry, i.e. genetic relationship among all individuals, is to adapt methods that combine information from pedigree, individual markers and population history (HERNÁNDEZ-SÁNCHEZ et al., 2004b). The gain in knowledge about the real situation in terms of calculating inbreeding rate and possibly trait-specific inbreeding depression within the dairy cattle population is of advantage, but it is just one side of the coin. Empirical and theoretical investigations led to the understanding of inbreeding in great detail. Increased inbreeding within some breeds is to be expected by efficient selection using reproductive technologies and statistical 
tools. The effect of linkage on controlling inbreeding in selection programs considering a whole genome was under study by FERNANDEZ et al. (2000). The general principle was minimising the average co-ancestries among selected individuals with a restriction in the loss of gain. Under linkage, the rate of inbreeding that is obtained by pedigree information can be different from the probability of identity by descent of genes. Following from that, when selecting for a major gene, the increase of the rate of inbreeding can be magnified for polygenes. Inbreeding makes the relationship between linkage disequilibrium and genetic distance difficult to predict (NSENGIMANA and BARET, 2004). These aspects strongly underline the fact that using the knowledge on inbreeding e.g. in QTL estimation could improve the outcome from those analyses considerably. The methodology suggested (HERNÁNDEZSÁNCHEZ et al., 2004b ) promises to be an advanced approach for solving such tasks. Furthermore, one main task of molecular biology is to uncover relationships between genes and their products. Current and future emphasize is on uncovering inbreeding effects in relation to gene expression and physiology of populations (KRISTENSEN et al., 2004).

\section{References}

AIPL:

Inbreeding coefficients for Holstein cows. August 2004. http://aipl.arsusda.gov/dynamic/inbrd/current/HOt.html (accessed 11-1-04).

BIEDERMANN, G.; WALDMANN, S.; MAUS, F.:

Genetische Analyse der Populationen des Hinterwälder Rindes. Arch. Tierz., Dummerstorf 46 (2003) 4, 307-319

BIJMA, P.; WOOLIAMS, J. A.:

Perdiction of genetic contributions and Generation intervals in Populations with overlapping generations under selection. Genetics 151 (1999), 1197-1210

BRADE, W.

Bewertung von Probanden aufgrund ingezüchteter Nachkommen - ein Überblick. Arch. Tierz., Dummerstorf 34 (1991) 5, 379-389

CASSELL, B. G.:

Optimal genetic improvement for the high producing cow. Dairy Sci. 84 (2001), E144-E150

CASSELL, B. G.; ADAMEC, V.; PEARSON, R. E.:

Effect of incomplete pedigrees on estimates of inbreeding and inbreeding depression for days to first service and summit milk yield in Holsteins and Jerseys. J. Dairy Sci. 86 (2003a), 2967-2976

CASSELL, B. G.; ADAMEC, V.; PEARSON, R. E.:

Paternal and maternal inbreeding depression for 70-Day Nonreturn and Calving Rate in Holsteins and Jerseys. J. Dairy Sci. 86 (2003b), 2977-2983

FERNANDEZ, B.; SANTIAGON, E.; TORO, M. A.; CABALLERO, A.:

Effect on linkage on the control of inbreeding in selection programmes. Genet. Sel. Evol. 32 (2000), 249-264

FLURY, C.; SIMIANER, H.:

Mean Epistatic Kinship - a new tool for the analysis of short-term pylogenetic structures. EAAP- $55^{\text {th }}$ Annual Meeting, Bled Book of Abstracts (2004) page 29

HERNÁNDEZ-SÁNCHEZ, J.; HALEY, C. S.;WOOLLIAMS, J. A.:

On the prediction of simultaneous inbreeding coefficients at multiple loci. Genetical Research Cambridge 83 (2004a), 113-120

HERNANDEZ-SANCHEZ, J.; HALEY, C.S.; WOOLLIAMS, J.A.:

Prediction of IBD based on population history for fine gene mapping.

Genetics (2004b) submitted

LYNCH, M.; WALSH, B.:

Genetics and analysis of quantitative traits. Sinauer Ass. Inc. Pub. USA,(1998)

KRISTENSEN, T. N.; SORENSEN, P.; KRUHOFFER, M.; PEDERSEN, K. S.; LOESCHKE, V.:

Gene expression profiles in inbred and non-inbred Drosophila melanogaster. EAAP- $55^{\text {th }}$ Annual Meeting, Bled Book of Abstracts (2004) page 84

MEUWISSEN, T.; GODDARD, M. E.: 
Prediction of identity-by-descent probabilities from marker-haplotypes. GSE 33 (2001), 605-634

NSENGIMANA, J.; BARET, P. V.:

Linkage disequilibrium and the genetic distance in livestock populations: the impact of inbreeding. Genet. Sel. Evol. 36 (2004); 281-296

PANICKE, L.; RYBKA, P.; ENGEL, S.; SCHÜLER, E.; ANACKER, G.; LEMBKE, K.:

Studie - Möglichkeit für die planmäßige Nutzung von Heterosis und Inzucht in der Milchrindzüchtung. Forschungszentrum für Tierproduktion Dummerstorf (1975)

PANICKE, L.; FREYER, G.:

Estimation of addtive and nonadditive effects in dairy cattle. Arch. Tierz., Dummerstorf 35 (1992)6, 537-549

PIRCHNER, F.:

Schätzung inzuchtwirksamer (effektiver) Populationsgrößen aus Genfrequenzschwankungen beim Bayerischen Fleckvieh und Tiroler Grauvieh. Arch. Tierz., Dummerstorf 45 (2002) 4, 331-339

PIRCHNER, F.:

Use of inbred sires to exploit epistatic variance. Arch. Tierz., Dummerstorf 47 (2004) 6, 605-608

PONG-WONG, R.; GEORGE, A. W.; WOOLLIAMS, J. A.; HALEY, C. S.:

A simple and rapid method for calculating identity-by-descetn matrices using multiple markers. GSE 33 (2001), 453-471

SANCHEZ, L.; BIJMA, P.; WOOLIAMS, J. A.:

Minimizing inbreeding by managing genetic contributions across generations. Genetics 164 (2003), 1589-1595

SMITH, L. A.; CASSELL, B.; PEARSON, R. E.:

The effects of inbreeding on the life time performance of dairy cattle. J. Dairy Sci. 81 (1998), 27292737

SORENSEN, C. A.; SORENSEN, M. K.; BERG, P.:

Inbreeding in Danish dairy cattle populations. EAAP- $55^{\text {th }}$ Annual Meeting, Bled Book of Abstracts (2004) page 30

SWALVE, H.H.:

Kreuzungszucht: Auch beim Milchrind eine Alternative? Rind Aktuell , Heft 14/2002, 25-29

THOMPSON, E.A.; HEATH, S.C.:

Estimation of conditional multilocus gene indentiy among relatives. In Statistics in molecular biology (1999), p 95-113, Ed F Seillier-Moseiwitch, P Donnelly, M Waterman. Springer-Verlag, IMS Lecture Series, NY

WANG, T.; FERNANDO, R. L.; VAN DER BEEK, S.; GROSSMAN, M.; VAN ARENDONK, J. A. M.:

Covariance between relatives for a marked quantitative trait locus. Genet. Sel. Evol. 27 (1995), 251-274

WEIGEL, K. A.; LIN, S. W.:

Use of computerized mate selection programs to control inbreeding of Holstein and Jersey cattle in the next generation. J. Dairy Sci. 83 (2000), 822-828

WEIR, B. S.; COCKERHAM, C. C.

Group inbreeding with two linked loci. Genetics 63 (1969), 711-742

WEIR, B. S.; COCKERHAM, C. C.:

Behavior of pairs of loci in finite monoecious populations. Theoretical Population Biology 6 (1974), 323-354

WRIGHT, S.:

Coefficients of inbreeding and relationship. American Naturalist 56 (1922), 330-339

ZELLER, K.; PIRCHNER, F.:

Verwendung von ingezüchteten Bullen in der Zuchtarbeit. Arch. Tierz., Dummerstorf 36 (1993) 3/4, 245-264

Received: 2004-12-14

Accepted: 2005-03-09

Authors' addresses

Prof. Dr. BENNET G. CASSELL*

Dr. JULES HERNÁNDEZ-SÁNCHEZ

VPISU Dairy Science Department Roslin Institute (Edinburgh)

2140 Litton Reaves Hall

VA-24060 Blacksburg/USA

Genetics and Genomics, Roslin

Midlothian, EH25 9PS, UK

Dr. GERTRAUDE FREYER

Research Institute for the Biology of Farm Animals (FBN)

Wilhelm-Stahl-Allee 2, 18196 DUMMERSTORF / GERMANY

* Corresponding author (E-mail: bcassell@vt.edu) 